Jurnal Keuangan dan Perbankan, Vol.20, No.1 Januari 2016, hlm. 22-31

Terakreditasi SK. No. 040/P/2014

http://jurkubank.wordpress.com

\title{
PENGARUH RASIO KEUANGAN DAN PERUBAHAN PAJAK DIVIDEN TERHADAP DIVIDEND PAYOUT RATIO PERUSAHAAN TERBUKA
}

\author{
Cahyo Dwi Sulistiyo \\ Sri Hartoyo \\ Tb Nur Ahmad Maulana \\ Program Pascasarjana M anajemen dan Bisnis IPB \\ Jl. Raya Pajajaran No.2, Kota Bogor, Jawa Barat 16128
}

\begin{abstract}
Theobjective of this research was to analyseinfluence company performance ratio such as ROA, DER, Size, EPS, C urrent Ratio, G rowth and changes in dividend tax rates to $D$ ividend $P$ ay out $R$ atio. The variables tested using panel regression analysis. Research conducted on 40 emitens included in LQ 45 index of Indonesia Stock Exchange (ISE) with years of research covering 2006 to 2012. The panel regression results show that the variables RO A , Current Ratio, Size, andG rowth showed a significant effect on dividend payout ratio, whilethe variable DER, EPS, and Tax have no significant effect on the dividend payout ratio but all the variable simultaneously influential to dividend payout ratio.
\end{abstract}

Keyw ords: Financial Ratio, D evidend Tax, D evidend Payout R atio, P anel Regression

Investor memiliki tujuan utama dalam berinvestasi yaitu untuk memperoleh hasil investasi yang dapat berupa pendapatan dividen maupun pendapatan dari selisih harga jual saham terhadap harga belinya. Dividen adalah distribusi pendapatan perusahaan yang merupakan hak pemegangsaham yang dapat berbentuk kas, aktiva atau bentuk lain. Kebijakan dividen adalah kebijakan untuk membagi keuntungan kepada pemegang saham yang akan di bagikan dalam bentuk dividen dan besaran laba ditahan untuk kebutuhan perkembangan usaha (Gitosudarmo dan Basri, 2008). Proporsi yang dibayarkan kepada pemegang saham bergantung pada kemampuan perusahaan menghasilkan laba dan kebijakan dividen yang diterapkan oleh perusahaan. Prosentase laba yang dibayarkan dalam bentuk dividen kepada pemegang saham disebut dividend payout ratio(DPR).

Pembagian dividen sangat dipengaruhi oleh pandangan para stakeholderdalam hal ini manajer

Korespondensi dengan Penulis:

Cahyo Dwi Sulistiyo: Telp. -

Email: - 


\section{Pengaruh Rasio Keuangan dan Perubahan Pajak Dividen terhadap Dividend Payout Ratio Perusahaan Terbuka}

Cahyo D wi Sulistiyo, Sri H artoyo, \& Tb Nur Ahmad Maulana

keuangan dan investor dalam menilai dividen. Pandangan para stakeholder dalam menilai dividen digambarkan dalam beberapa teori dividen. Beberapa teori kebijakan dividen meliputi teori Dividen Tidak Relevan, teori The Bird in the $\mathrm{H}$ and, teori perbedaan pajak, teori Signaling Hipothesis serta teori Clientelle Effect.

Teori Dividen Tidak Relevan yang dikemukakan Modigliani dan Miller (1961) berpendapat, nilai suatu perusahaan tidak ditentukan oleh besar kecilnya D ividend Payout Ratio, tapi ditentukan oleh laba bersih sebelum pajak dan kelas risiko perusahaan. Teori ini menyimpulkan dividen tidak re levan untuk diperhitungkan karenatidak akan meningkatkan kesejahteraan pemegang saham.

Lintner (1962) berpendapat bahwa investor lebih merasa aman untuk memperoleh pendapatan berupa pembayaran dividen daripada menunggu capital gain yang dikenal dengan teori The Bird in the $\mathrm{H}$ and. Pendapat ini beranggapan bahwa investor memandang lebih berharga "satu burung di tangan daripada seribu burung di udara" dengan kata lain kemungkinan capital gain yang diharapkan adalah lebih besar risikonya dibandingkan dengan dividend yield yang pasti.

Teori perbedaan pajak (Tax Preference/ D ifference Theory) berpendapat bahwa dengan adanya preferensi pajak atas dividen dan capital gain sebaiknya dividen tidak terlalu banyak dibayarkan. Litenberger dan Ramaswamy (1979) mengatakan bahwa sebaiknya pembayaran dividen dapat ditunda apabila pajak atas capital gain masih lebih rendah dari pajak atas dividen. $\mathrm{Hal}$ ini disebabkan karena pajak atas capital gain baru akan terealisasi pada saat ada penjualan aktiva atau saham, sedangkan pajak atas dividen harus dibayarkan segera pada saat perusahaan membagikan dividen.

Bhattacharya (1979) menjelaskan teori Signaling $\mathrm{H}$ ipothesis yang mengungkapkan bahwa adanya informasi asimetri antara para pemegang saham (outsider) dan para manajer memungkinkan para manajer untuk menggunakan dividen sebagai pemberi sinyal (informasi) tentang kinerja perusahaan kepada para pemegang saham. Dividen menyelaraskan ketidakseimbangan informasi antara para manajer dan pemegang saham dengan cara memberi informasi tentang prospek perusahaan di masa depan. Kenaikan dividen biasanya merupakan suatu sinyal kepada para investor bahwa manajemen perusahaan meramalkan suatu penghasilan yang baik di masa mendatang. Sebaliknya, penurunan dividen atau kenaikan dividen yang dibawah kenaikan normal diyakini investor sebagai suatu sinyal bahwa perusahaan menghadapi masa sulit di waktu mendatang.

Teori Clientelle Effect yang dikemukakan Miller dan Scholes (1978) menyatakan bahwa kelompok (clientele) pemegang saham yang berbeda akan memiliki preferensi yang berbeda terhadap kebijakan dividen perusahaan. Kelompok pemegang saham yang membutuhkan penghasilan pada saat ini lebih menyukai suatu Dividend Payout Ratio yang tinggi. Sebaliknya kelompok pemegang saham yang tidak begitu membutuhkan uang saat ini lebih senang jika perusahaan menahan sebagian besar laba bersih perusahaan.

Signalling Theory dan tax preferencetheory menjadi teori yang melandasi penelitian ini untuk melihat keterkaitan kinerja perusahaan yang tercermin dalam rasio-rasio keuangan serta penurunan tarif atas dividen terhadap kebijakan dividen yang direpresentasikan sebagai dividend payout ratio. Rasio keuangan menunjukkan kinerja keuangan perusahaan meliputi ukuran likuiditas, profitabilitas, solvabilitas sedangkan kebijakan penurunan tarif pajak dividen diharapkan dapat mendorong perusahaan semakin meningkatkan pemberian dividen kepada pemegang saham.

Beberapa penelitian mengenai faktor-faktor yang mempengaruhikebijakan DPR di Indonesia namun belum meneliti dampak perubahan kebijakan besaran tarif pajak dividen terhadap kebijakan DPR. Hal ini memunculkan pertanyaan, bagaimanakah pengaruh faktor-faktor yang telah 


\section{Jurnal Keuangan dan Perbankan | KEUANGAN}

Vol. 20, N o.1, Januari 2016: 22-31

diteliti tersebut apabila dikombinasikan dengan perubahan tarif pajak dividen. Oleh karena itu diperlukan suatu penelitian yang mengandung kebaruan tentang faktor-faktor yang mempengaruhi kebijakan DPR dengan mengikutsertakan faktor perubahan tarif pajak dividen sebagai variabel baru yang patut diuji pengaruhnya. Faktor-faktor yang dibahas dalam penelitian ini adalah rasio keuangan meliputi D ebt Equity Ratio (DER), R eturn On Asset (ROA), ukuran perusahaan (Size), pertumbuhan penjualan (Growth of Sales), Earning Per Share (EPS) serta perubahan tarif pajak deviden.

Menurut Azhari (2005), D ebt to Equity Ratio adalah rasio yang menunjukan persentase penyediaan dana oleh pemberi pinjaman terhadap pemegang saham. Semakin tinggi rasio, semakin rendah pendanaan perusahaan yang disediakan oleh pemegang saham. Dari perspektif kemampuan membayar kewajiban jangka panjang, semakin rendah rasio akan semakin baik kemampuan perusahaan dalam membayar kewajiban jangka panjangnya. Pemilihan variabel bebas berupa kebijakan hutang (rasio keuangan hutang/ DER) didasarkan pada penelitian Jensenet al (1992), M ahmoud etal. (1995) serta Sartono (2001)yang menyatakan bahwa terdapat pengaruh negatif antara hutang dan dividen. Perusahaan yang banyak mempunyai hutang cenderung memberikan dividen yang rendah untuk melunasi hutang-hutangnya.

Variabel bebas ukuran profitabilitas (ROA) juga telah diteliti untuk mengetahui pengaruhnya terhadap kebijakan deviden. Hanafi dan Halim (2003) menyatakan bahwa rasio Return on A ssets (ROA) mengukur kemampuan perusahaan menghasilkan laba bersih berdasarkan tingkat asset tertentu. Demikian juga Lukman (2007) mengatakan bahwa Return on A sset (ROA) merupakan pengukuran kemampuan perusahaan dalam menghasilkan keuntungan dengan jumlah keseluruhan aktiva yang tersedia, semakin tinggi rasio ini berarti semakin baik keadaan suatu perusahaan. Baker et al. (1985), Pruitt dan Gitman (1991) menemukan bahwa faktor penentu utama pembayaran dividen adalah pendapatan perusahaan di masa mendatang yang stabil. Perusahaan yang memiliki pendapatan yang relatif stabil cenderung memiliki dividend payout ratio yang lebih besar dibandingkan dengan perusahaan yang memiliki pendapatan yang berfluktuasi. Penelitian Utami (2008), Sumiadji (2011), Wicaksana (2012), menunjukkan bahwa rasio Return on Assets (ROA) berpengaruh positif signifikan terhadap DPR.

Perusahaan yang memiliki ukuran besar akan lebih mudah memasuki pasar modal sehingga dalam hal ini kesempatan perusahaan membayar dividen besar kepada pemegang saham lebih besar daripada perusahaan dengan ukuran kecil. Hal ini disebabkan karena pada perusahaan kecil, profit dialokasikan pada laba ditahan yang digunakan untuk menambah aset. Penelitian Chang dan Rhee (1990), Holder et al. (1998), Cleary (1999), Imran (2011)menyatakan variabel ukuran perusahaan (firm size) berpengaruh positif terhadap kebijakan pemberian dividen kepada pemegang saham.

Pertumbuhan penjualan merupakan indikator permintaan dan daya saing perusahaan dalam suatu industri. Laju pertumbuhan suatu perusahaan akanmempengaruhi kemampuan mempertahankan keuntungan dalam mendanai kesempatan pada masa yang akan datang (Barton et al. 1989). Penelitian Rahmawati (1999)menyatakan variablegrowth of sales mempunyai pengaruh positif yang signifikan terhadap kebijakan pemberian deviden.

Tingkat keuntungan per lembar saham (EPS) merupakan indikator untuk menilai suatu perusahaan dalam meningkatkan keuntungannya. Semakin besar nilai EPSmenunjukkan perusahaan mampu memberikan laba yang lebih tinggi bagi investor. Penelitian Sumiadji (2011), Rahmawati(1999), Sunarto dan Kartika (2003) menemukan bahwa EPS berpengaruh signifikan positif terhadap dividend payout ratio.

Current ratio merupakan ukuran rasio likuiditasyang dihitung dengan membagi aktiva lancar 


\section{Pengaruh Rasio Keuangan dan Perubahan Pajak Dividen terhadap Dividend Payout Ratio Perusahaan Terbuka}

Cahyo D wi Sulistiyo, Sri H artoyo, \& Tb Nur Ahmad Maulana

dengan hutang lancar. Semakin besar current ratio menunjukkan semakin tinggi kemampuan perusahaan membayar hutang jangka pendeknya termasuk kewajiban membayar dividen yang dijanjikan. (Brigham dan Houston 2006). Penelitian Suharli dan Oktorina (2005), Budiarto (2009), dan Karami (2011) menyatakan bahwa ukuran kelancaran keuangan perusahaan (current ratio) mempengaruhi secara signifikan positif terhadap kebijakan dividen.

Dampak penurunan pajak atas dividen telah diteliti oleh para ahli selama beberapa dekade. Penelitian dari Dharmapala (2009), Blouin et al.(2004), Chetty dan Saez (2005) menunjukkan bahwa penurunan tarif pajak dividen di Amerika pada tahun 2003 (yang dikenal dengan program Jobs and Growth Tax Relief Reconciliation A ct/JGTRRA) menghasilkan respon positif terhadap dividend payout ratio perusahaan-perusahaan di Amerika Serikat, dalam hal ini penurunan pajak memiliki dampak yang signifikan positif terhadap pembayaran dividen. Namun di Indonesia, dampak penurunan pajak dividen yang berlaku efektif di tahun 2009 masih belum dilakukan penelitian.

Penelitian ini bertujuan untuk menguji pengaruh DER, ROA, Size, EPS, CR, Growth of Sales serta perubahan tarif pajak deviden secara simultan maupun parsial terhadap kebijakan deviden pada perusahaan terbuka yang termasuk dalam indeks LQ 45BEI. Indeks LQ 45 adal ah nilai kapital isasi pasar dari 45saham yang paling likuid dan memiliki nilai kapitalisasi yang besar. Pembagian dividen yang relatif rutin setiap tahun dibagikan oleh perusahaan besar dalam indeks LQ 45 dalam periode tahun pengamatan diharapkan dapat menghasilkan data yang lebih akurat tentang pengaruh penurunan tarif pajak dividen terhadap besaran dividen yang dibagikan.

\section{HIPOTESIS}

Berdasarkan teori serta hasil penelitian terdahulu maka hipotesis dalam penelitian ini dapat diuraikan sebagai berikut:
$\mathrm{H}_{1}$ : Return on Assets(ROA) berpengaruh positif terhadap dividend payout ratio

$\mathrm{H}_{2}$ : D ebt Equity Ratio(DER) berpengaruh negatif terhadap dividend payout ratio

$\mathrm{H}_{3}$ : Ukuran perusahaan (Size) berpengaruh positif terhadap dividend payout ratio

$\mathrm{H}_{4}$ : Earning Per Share (EPS) berpengaruh positif terhadap dividend payout ratio

$\mathrm{H}_{5}$ : Current Ratio(CR) berpengaruh positif terhadap dividend payout ratio

$\mathrm{H}_{6}$ : Growth of Sales(Growth) berpengaruh positif terhadap dividend payout ratio

$\mathrm{H}_{7}$ : Perubahan kebijakan penurunan tarif pajak (Tax) berpengaruh positif terhadap dividend payout ratio

\section{METODE}

Populasi dalam penelitian ini adalah seluruh perusahaan terbuka yang termasuk dalam indeks LQ 45 yang terdafar di Bursa Efek Indonesia pada tahun 2006 sampai dengan tahun 2012. Metode pemilihan sampel yang digunakan dalam penelitian adalah purposive sampling dengan kriteria sebagai berikut:

1. Dalam periode 2006-2012, perusahaan terus terdaftar dalam Bursa Efek Indonesia dan tidak terkena daftar delisting.

2. Tahun fiskal Iaporan keuangan perusahaan berakhir pada bulan Desember.

3. Laporan keuangan perusaahan sampel memenuhi rasio-rasio keuangan yang dibutuhkan dalam penelitian ini.

Dari 335 perusahaan-perusahaan yang terdaftar di Bursa Efek Indonesia mulai tahun 2006 sampai 2012 diperoleh sampel penelitian 40 perusahaan yang termasuk dalam daftar indeks LQ 45 yang sesuai dengan kriteria penelitian (Tabel 1) 


\section{Jurnal Keuangan dan Perbankan | KEUANGAN}

Vol. 20, N o.1, Januari 2016: 22-31

Data yang digunakan merupakan data sekunder yang bersumber dari laporan keuangan 40 perusahaan go public yang terdaftar dalam daftar LQ 45 Bursa Efek Indonesia tahun 2013 untuk periodelaporan keuangan tahun 2006-2012. Pemilihan tahun pengamatan mulai dari tahun 2006 sampai dengan tahun 2012 karena terdapat periode tahun yang berimbang pada saat sebelum dan sesudah perubahan kebijakan tarif pajak atas dividen yang berlaku pada tahun 2009.

Pada penelitian ini variabel terikat adalah $D$ ividend $P$ ay out $R$ atio (DPR) yang merupakan rasio antara laba yang dibayarkan dalam bentuk deviden dengan total laba yang tersedia bagi pemegang saham.Variabel-variabel bebas yang diduga mempengaruhi tingkat D ividend $P$ ay out Ratio (DPR) yaitu:

a. ROA, merupakanReturn on A sset, yaitu rasio antara Laba Setelah Pajak terhadap Total Assets. Satuan yang digunakan adalah persen.

b. DER, merupakanD ebt to Equity Ratio, yaitu rasio antara Total Kewajiban terhadap Total E kuitas. Satuan yang digunakan adalah persen. c. Size, merupakan variable ukuran perusahaan, yang direpresentasikan dengan menggunakan natural log total asset.

d. EPS, merupakan variable Earning Per Share, yaitu rasio antara laba bersih setelah pajak terhadap jumlah lembar saham yang beredar (outstanding share).

e. Current, merupakan variableC urrent Ratio (CR), yaitu rasio antara current asset dan current liabilities.

f. Growth, merupakan variabelgrowth of sales. Satuan yang digunakan adalah persen.

g. Dummy (Tax), merupakan perubahan tarif pajak atas deviden, yaitu 0 untuk tahun 2006 sd 2008 dan 1 untuk tahun pajak 2009 sd 2012

Ikhtisar rata-rata tingkat DPR beserta besaran variabel bebas seperti ROA, DER, CR dan $G$ rowth dalam satuan prosentase serta besaraan EPS dan Sizedari 40 perusahaan sample penelitian dari tahun 2006 sampai dengan tahun 2012 dapat dilihat pada tabel 2.

Tabel 1. Data Populasi dan Sampel Perusahaan Perusahaan Periode 2006-2012

\begin{tabular}{lc}
\hline Kriteria & Jumlah \\
\hline Perusahaan terdaftar di LQ 45 & 45 \\
Perusahaan tidak rutin membagi dividen 2006-2012 & 5 \\
Perusahaan rutin membagi dividen 2006-2012 & 40 \\
Perusahaan yang dijadikan sampel & 40 \\
\hline
\end{tabular}

Tabel 2. Rata-rata Nilai Variabel Penelitian

\begin{tabular}{rrrrrrrr}
\hline Tahun & $\begin{array}{r}\text { D PR } \\
\mathbf{( \% )}\end{array}$ & $\begin{array}{r}\text { ROA } \\
\mathbf{( \% )}\end{array}$ & $\begin{array}{r}\text { DER } \\
\mathbf{( \% )}\end{array}$ & $\begin{array}{r}\text { CR } \\
\mathbf{( \% )}\end{array}$ & $\begin{array}{r}\text { Growth } \\
\mathbf{( \% )}\end{array}$ & EPS & Size \\
\hline 2006 & 26,58 & 8,84 & 185,12 & 169,95 & 27,60 & 117,54 & 16,07 \\
2007 & 43,20 & 11,95 & 125,73 & 197,46 & 53,55 & 205,58 & 16,32 \\
2008 & 8,35 & 10,03 & 129,12 & 208,83 & 27,49 & 268,55 & 16,54 \\
2009 & 26,14 & 11,64 & 84,44 & 213,51 & 9,76 & 387,02 & 16,62 \\
2010 & 33,65 & 12,57 & 57,56 & 219,86 & 24,06 & 359,28 & 16,77 \\
2011 & 36,93 & 13,79 & 51,88 & 255,08 & 25,04 & 505,73 & 16,95 \\
2012 & 34,64 & 12,59 & 116,17 & 220,79 & 17,64 & 495,66 & 17,15 \\
\hline
\end{tabular}

Sumber: Laporan keuangan audited emiten ISE indeks LQ 45 


\section{Pengaruh Rasio Keuangan dan Perubahan Pajak Dividen terhadap Dividend Payout Ratio Perusahaan Terbuka}

Cahyo D wi Sulistiyo, Sri H artoyo, \& Tb Nur Ahmad Maulana

Model penelitian dalam menganalisis pengaruh variabel bebas terhadap variabel terikat merupakan model regresi linear berganda yang dapat dirumuskan dengan persamaaan regresi sebagai berikut:

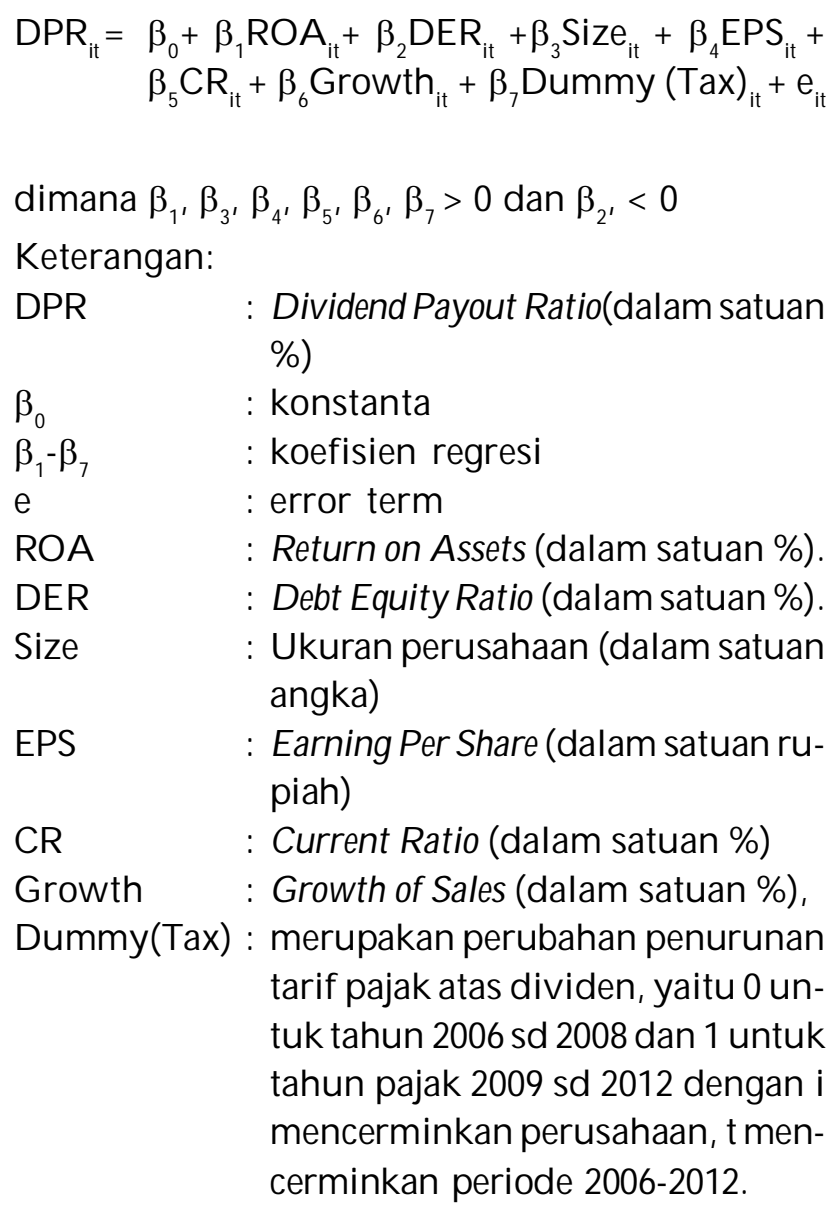

\section{HASIL}

Pengujian model regresi berganda dilakukan untuk menguji pengaruh dari ke-7 variabel bebas berupa likuiditas, profitabilitas dan leverage, serta kebijakan penurunan pajak atas dividen terhadap dividend payout ratio. Seluruh variabel yang digunakan dalam model regresi ini tidak terdapat permasalahan multikolineritas serta menggunakan metode General Least Square (C ross Section W eight) yang merupakan metode perbaikan dari heteroskedastisitas, maka data yang diolah dianggap sudah tidak mengandung heteroskedastisitas. Hasil pengujian asumsi klasik multikolinearitas dapatdilihat dalam tabel 3.

Berdasarkan hasil diatas terlihat korelasi antar variabel independen semuanya dibawah 0.5 yang menunjukkan tidak terdapat korelasi linear sempurna antar variabel bebas atau tidak ada multikolinearitas.

Nilai d hitung diperoleh dari output regresi pengolahan data e-views dalam kolom DurbinWatson adalah sebesar 1.794 yang menyimpulkan bahwa tidak terdapat autokorelasi pada satu observasi dengan observasi lain. Pada tabel DurbinWatson dengan tingkat signifikansi $1 \%$ diperoleh nilai dL sebesar 1.680 dan dU sebesar 1.767 , sehingga nilai $d$ terletak pada daerah dU $<$ d $<4$-dU atau $1.767<1.794<2.233$, yang dapat disimpulkan tidak terdapat autokorelasi pada model regresi.

Tabel 3. Hasil pengujian korelasi antarvariabel independen

\begin{tabular}{llllllll}
\hline & CR & DER & EPS & GROWTH & SIZE & ROA & TAX \\
\hline CR & - & -0.190 & 0.065 & 0.037 & -0.181 & 0.232 & 0.112 \\
DER & -0.190 & - & -0.170 & 0.020 & -0.058 & -0.256 & -0.113 \\
EPS & 0.065 & -0.170 & - & -0.048 & 0.128 & 0.463 & 0.205 \\
G ROWTH & 0.037 & 0.020 & -0.048 & - & -0.090 & 0.001 & -0.167 \\
SIZE & -0.181 & -0.058 & 0.128 & -0.090 & - & -0.186 & 0.195 \\
ROA & 0.232 & -0.256 & 0.463 & 0.001 & -0.186 & - & 0.107 \\
TAX & 0.112 & -0.113 & 0.205 & -0.167 & 0.195 & 0.107 & - \\
\hline
\end{tabular}




\section{Jurnal Keuangan dan Perbankan | KEUANGAN}

Vol. 20, N o.1, Januari 2016: 22-31

Tabel 4 menunjukkan hasil dari regresi model penelitian dengan tingkat koefisien determinasi (R-squared) sebesar 0.75 atau sebesar $75 \%$ berarti bahwa variasi Dividend Payout Ratio (DPR) yang dapat dijelaskan oleh variasi dari variabelvariabel yang masuk dalam penelitian ini adalah sebesar 75\%. Sedangkan sisanya 25\% dijelaskan oleh faktor lain yang tidak diikutsertakan dalam model penelitian ini. Faktor lain yang belum dimasukkan dalam penelitian sal ah satunya data berupa preferensi investor atas imbal hasil investasi berupa dividen atau capital gain sesuai teori dividen Clientelle Effect. Nilai probabilitas (F-stat) yang mempunyai nilai sebesar 0.0000 adalah siginifikan pada $1 \%$ tingkat signifikan yang berarti variabel bebas secara bersama-sama signifikan mempengaruhi variabel terikatnya pada tingkat $\alpha=1 \%$.

V ariable R eturn 0 n A sset (ROA) secara parsial berpengaruh signifikan positif terhadap Dividend Payout Ratio (DPR) dengan nilai koefisien regresi 0,269, t hitung 2,376 dan siginifikan 0,009 dimana nilainya dibawah 0,05 . Hasil ini sesuai dengan hipotesa yang menjelaskan bahwa perubahan pada ROA akan mempengaruhi DPR, yang berarti apabila terjadi peningkatan laba akan berdampak pada meningkatnya kemampuan membayar deviden dan para pemegang saham akan menerima hasil investasinya. Hasil penelitian ini konsisten dengan hasil penelitian sebelumnya yang antara lain dilakukan oleh Utami (2008),Sumiadji (2011), Wicaksana (2012) yang menunjukkan bahwa berdasar hasil penelitian mereka, ROA berpengaruh positif signifikan terhadap DPR.

$V$ ariable Debt Equity Ratio (DER) tidak berpengaruh secara signifikan terhadap D ividend Payout Ratio (DPR) dengan nilai koefisien regresi 0,0022 , t hitung sebesar $-0,52474$ dan probabilitas 0,300 dimana nilainya diatas 0,05. Hasil ini tidak sesuai dengan hipotesa namun nilai koefisien negatifberarti yaitu semakin besar DER akan menyebabkan DPR menurun. Hal ini berarti semakin besar penggunaan dana yang bersumber dari eksternal (kreditor) akan menurunkan kesempatan investor untuk memperoleh dividen. Hasil ini disebabkan terdapat perusahaan yang mempunyai nilai DER sangat besar namun tetap memberikan deviden dalam jumlah lebih besar dari tahun sebel umnya agar saham perusahaan tetap menarik dan diminati investor dan tetap termasuk dalam Indeks LQ 45.

Tabel 4 Hasil Regresi

\begin{tabular}{lll}
\hline Variable & Coefficient & Prob (1-tailed) \\
\hline ROA & 0.269 & 0.009 \\
DER & -0.002 & 0.300 \\
SIZE & 5.071 & 0.016 \\
EPS & -0.007 & 0.094 \\
CR & 0.013 & 0.032 \\
GROWTH & -0.009 & 0.049 \\
TAX & 1.526 & 0.263 \\
C & -58.961 & 0.060 \\
\hline Weighted Statistics & & \\
R-squared & 0.750 & \\
Adjusted R-squared & 0.701 & \\
F-statistic & 15.219 & \\
Prob(F-statistic) & 0.000 & \\
Durbin-Watson stat & 1.794 & \\
\hline
\end{tabular}




\section{Pengaruh Rasio Keuangan dan Perubahan Pajak Dividen terhadap Dividend Payout Ratio Perusahaan Terbuka}

Cahyo D wi Sulistiyo, Sri H artoyo, \& Tb Nur Ahmad Maulana

V ariable SIZE secara parsial berpengaruh signifikan positif terhadap DPR dengan nilai koefisien regresi 5,070, t hitung 2,145 dan siginifikan 0,016 dimana nilainya dibawah 0,05 . Hal ini sejalan dengan hipotesa dan penelitian Imran (2011), Cleary (1999), perusahaan besar dengan akses pasar yang lebih baik seharusnya membayar dividen yang tinggi kepada pemegang sahamnya, sehingga antara ukuran perusahaan dan pembayaran deviden memiliki hubungan yang positif signifikan

$\checkmark$ ariableEPStidak berpengaruh secara signifikan terhadap DPR dengan nilai koefisien regresi $-0,0073$, t hitung sebesar $-1,31944$ dan signifikan 0,094 dimana nilainya diatas 0,05 . Hasil ini tidak sesuai dengan hipotesa yang disebabkan terdapat perusaahan yang disaat mengalami negatif earning (merugi)tetap membagikan dividen agar saham perusahaan tetap menarik untuk diperjualbelikan investor di bursa efek dan tetap termasuk dalam Indeks LQ 45.

$V$ ariable $C R$ berpengaruh signifikan positif terhadap D PR dengan nilai koefisien regresi 0,0133, t hitung 1,8555 dan siginifikan 0,032 dimana nilainya dibawah 0,05 (signifikan pada $\alpha=5 \%$ ). Hal ini sesuai dengan teori menjelaskan bahwa semakin mampu perusahaan melunasi kewajiban lancarnya, berdampak pada kemampuan membayar deviden. Kreditor dan investor, keduanya dapat menikmati hasil atas pemberian kredit dan investasinya. Hasil penelitian ini konsisten dengan hasil penelitian sebel umnya yang antara lain telah dilakukan oleh Suharli dan Oktorina (2005), Budiarto (2009), dan Karami (2011) dimana hasil penelitian mereka menuukkan bahwa Current Ratio berpengaruh positif signifikan terhadap DPR.

V ariable GROWTH berpengaruh signifikan dengan arah negatif terhadap DPR dengan nilai koefisien regresi -0,00936, t hitung -1,66278 dan siginifikan 0,049 dimana nilainya dibawah 0,05 (signifikan pada $\alpha=5 \%$ ). Hasil regresi ini sesuai dengan penelitian Chang dan Rhee (1990), Rahmawati (1999), Sutoyo (2011)yang menyatakan bahwa semakin cepat tingkat pertumbuhan perusahaan, semakin besar kebutuhan dana untuk membiayai ekspansi usaha. Kebutuhan dana dapat berasal dari internal maupun eksternal perusahaan. Kebutuhan danainternal perusahaan untuk keperluan ekspansi perusahaan akan mengurangi pembagian dividen oleh perusahaan kepada para pemegang saham. Penjelasan ini didukung terdapat perusahaan dalam penelitian memiliki rasio Growth yang tinggi di atas rata-rata growth dengan pembayaran dividennya yang hanya sebesar rata-rata DPR.

Variable TA X tidak berpengaruh signifikan terhadap DPR dengan nilai koefisien regresi 1,5263, t hitung sebesar 0,6340 dan signifikansi 0,263 dimana nilainya diatas 0,05 . A rtinya jika tarif pajak dividen meningkat atau menurun maka rasio DPR belum tentu meningkat atau menurun. Hasil yang menunjukkan bahwa variabel Tax tidak signifikan mempengaruhi DPR perusahaan-perusahaan yang terdaftar dalam LQ45 BEI atau penurunan tarif pajak deviden tidak cukup membuat perusahaan lebih banyak membagi deviden kepada investor. Dikaitkan dengan teori perbedaan pajak yang diajukan oleh Litzenberger dan Ramaswamy (1979), yang mendorong perusahaan untuk tidak memberikan dividen dengan memberikan keuntungan penghematan pajak dividen yang timbul apabila dividen dibagi dan pajak dapat ditunda melalui melalui pajak capital gainyang baru dibayar apabila saham dijual, perusahaan cenderung untuk tidak membagikan deviden dengan harapan cadangan laba dapat digunakan untuk keperluan investasi, perluasan usaha yang mendorong naiknya nilai perusahaan.

\section{KESIM PULAN}

Sesuai dengan tujuan penelitian serta berdasarkan hasil penelitian, analisis dan pembahasan faktor-faktor yang mempengaruhi dividend payout ratio maka dapat disimpulkan bahwa: 


\section{Jurnal Keuangan dan Perbankan | KEUANGAN}

Vol. 20, N o.1, Januari 2016: 22-31

1. rasio keuangan berupa $R O A, D E R, S I Z E, E P S$, CR, GROWTH dan TAX secara simultan atau bersama-sama berpengaruh terhadap DPR.

2. Rasio ROA, SIZE,CR, dan GROWTH secara parsial mempunyai pengaruh yang signifikan terhadap DPR. Sedangkan faktor-faktor yaitu DER, EPS, dan TAX (perubahan tarif pajak) tidak menunjukkan pengaruh yang signifikan terhadap DPR. Hal ini dimungkinkan dikarena terdapat perusahaan dengan rasio hutang yang tinggi, mengalami kerugian namun masih tetap membayarkan dividen bahkan dengan jumlah yang lebih tinggi demi menjaga agar sahamnya tetap menarik investor. Faktor pe nurunan tarif pajak dividen belum dirasakan menarik bagi perusahaan untuk membagi dividen yang dimungkinkan karena tarif pajak dividen masih terlalu tinggi dibanding capital gain yang hanya sebesar $0.1 \%$.

\section{SARAN}

Penelitian ini dilakukan dengan melihat rasio $D$ ividend Payout Ratio perusahaan-perusahaan yang terdaftar dalam index LQ45, dan tidak melihat secara langsung preferensi investor terhadap imbal balik investasi saham. Penelitian lebih lanjut dapat dilengkapi pembuatan kuesioner kepada investor mengenai preferensi investor terhadap imbal balik investasi terhadap capital gain atas penjual an saham atau terhadap dividen. Penelitian selanjutnya diharapkan dilakukan dengan jumlah tahun pengamatan yang lebih panjang dengan memperhatikan adanya kondisi krisis ekonomi ataupun perlambatan ekonomi dunia.

\section{DAFTAR PUSTAKA}

Azhari D. 2005. Pedoman Praktis Memahami Laporan Keuangan. Yogyakarta (ID): ANDI

Baker HK., Farrelly GE, Edelman RB. 1985. A Survey of Management Views on Dividend Policy. Financial Management Journal. 14(3):78-84
Barton SL, Ned CH, Sirinivasan S. 1989. An empirical test of stakeholder theory prediction of capital structure. Journal of Financeand Accounting. 26(3):393416

Bhattacharya, S. 1979. Imperfect information, dividend policyand the bird in the hand fallacy. Journal of Economics and Management Science.10(1):259270

Blouin JL, ReadyJS, Shackelford DA. 2004. Did dividends increase after the 2003 reduction in dividend tax rates? Working paper. Chappel Hill (US): University of $\mathrm{N}$ orth Carolina

Budiarto DS.2009. Prediksi Tingkat Pengembalian Investasi Sekuritas Pada Perusahaan Manufaktur Melalui Informasi Akuntansi Perusahaan. Jurnal A kamedika U niversitas PGRI Y ogyakarta. 3: 33-47

Chang RP, Rhee SG. 1990. The Impact of Personal Taxes on Corporate Dividend Policy and Capital Structure Decisions. Financial management. 19(2): 21- 31.

Chetty R, Saez E. 2005. Dividend taxes and corporate behavior: evidencefrom the2003 dividend tax cut. Quarterly Journal of Economics. 120(3):791-833.

Cleary, S. 1999, The Relationship between Firm Investment and Financial Status. The Journal of Finance, 54: 673-692.

Dharmapala D. 2009. The Impact of Taxes on Dividends and Corporate Financial Policy: Lessons from the 2000's". Washington DC (US): American Enterprise Institute Press.

Gitosudarmo, Basri. 2008 M anajemen Keuangan Edisi 4. Yogyakarta (ID): BPFE

Hanafi MM, Halim A. 2003. A nalisis Laporan Keuangan. Yogyakarta (ID): AMP -YKPN

Holder ME, Langrehr FW, Hexter JL 1998. Devidend Policy Determinants: An Investigation of the Influences of Stakeholder Theory. Financial $M$ anagement. 27(3): 73-82

Imran, K. 2011. Determinants Of Dividend Payout Policy: A Case Of Pakistan Engineering Sector. Romanian Economic Journal. 14(41): 47-60

Jensen GR, Solberg DP, Zorn TS. 1992. Simultaneous Determination of Insider Ownership, Debt, and Dividend Policies. Journal of Financial and Quantitative Analysis. 27(2): 247-263. 


\title{
Pengaruh Rasio Keuangan dan Perubahan Pajak Dividen terhadap Dividend Payout Ratio Perusahaan Terbuka
}

\author{
Cahyo D wi Sulistiyo, Sri H artoyo, \& Tb Nur Ahmad Maulana
}

Karami, LC. 2011. The Influence of Leverage and Liquidity on Dividend Policy (Empirical Study on Listed Companies in Indonesia Stock Exchange of LQ45 in 2008-2010. Jurnal IImiah M ahasiswa FEB M alang.

Lintner J. (1962). Dividends, earnings, leverage, stock prices and the supply of capital to corporations. The Review of Economics and Statistics. 44(3):243269.

Litzenberger RH, Ramaswamy K. 1979. The Effects of Personal Taxes and Dividends on Capital Asset Price: Theory and Empirical Evidence. Journal of Financial Economics. (7): 163-195

Lukman S. 2007. Manajemen Keuangan Perusahaan. Jakarta (ID): Raja Grafindo Persada.

Mahmoud AM, Perry LG, Rimbey JN. 1995. An Investigation ofthe Dynamic Relationship Between Agency Theory and Dividend Policy. Financial Review. 30(2):367-385

Miller MH, Modigliani F. 1961. Dividend policy, growth, and the valuation of shares. The Journal of Business. 34(4): 411-433

Miller MH, Scholes MS. 1978. Dividends and taxes. Journal of Financial Economics. 6(4):333-364

Pruitt SW, Gitman LJ. 1991. The interactions between the investment, financing, and dividend decisions of major US firms. Financial Review. 26(3):409-430

Rahmawati, A. 1999. A nalisis Variabel-Variabel Yang Mempengaruhi Pembayaran Deviden Per Lembar Saham Pada Perusahaan Go Public Di Indonesia. Tesis. (Tidak D ipublikasikan). Universitas Brawijaya.
Sartono, A. 2001. Manajemen Keuangan "Teoridan A plikasi". Edisi Keempat. Yogyakarta:BPFE

Suharli, Oktorina. 2005. Memprediksi Tingkat Pengembalian Investasi Pada Equity Securities Melalui Rasio Profitabilitas, Likuiditas, Dan Hutang Pada Perusahaan Publik Di Jakarta. Prosiding. Simposium Nasional Akuntansi Solo

Sumiadji. 2011. Analisis Variabel Keuangan Yang Mempengaruhi Kebijakan Dividen. Jurnal Dinamika A kuntansi. 3(2):129-138

Sunarto, Kartika A. 2003. A nalisis Faktor-Faktor Yang Mempengaruhi Deviden Kas Di Bursa Efek Indonesia. Jurnal Bisnis dan Ekonomi. 3(5): 198-224.

Sutoyo. 2011, Faktor-Faktor Yang Mempengaruhi Dividend Payout Ratio Pada Perusahaan Jasa Keuangan. Jurnal Keuangan dan Bank. 15(1): 76-83

Utami, RP. 2008. Pengaruh Rasio Keuangan Terhadap Deviden Pada Sektor Industri Manufaktur Yang Terdaftar Di Bursa Efek Indonesia Tahun 20032007. Tesis. (Tidak Dipublikasikan). Universitas Gunadarma

Wicaksana, IGA. 2012. Pengaruh Cash Ratio, Debt To Equity Ratio, Dan Return On Asset Terhadap Kebijakan Deviden Pada Perusahaan Manufaktur di Bursa Efek Indonesia. Tesis. (Tidak Dipublikasikan). Universitas Udayana 